\title{
References of Part IV
}

Almeida, J., S. Schobesberger, A. Kürten, I. K. Ortega, O. Kupiainen-Määttä, et al. Molecular understanding of sulphuric acid-amine particle nucleation in the atmosphere. Nature, 502(7471), 359-363, 2013.

Baker, D. N., T. I. Pulkkinen, X. Li, S. G. Kanekal, J. B. Blake, R. S. Selesnick, M. G. Henderson, G. D. Reeves, H. E. Spence, and G. Rostoker. Coronal mass ejections, magnetic clouds, and relativistic magnetospheric electron events: ISTP. Journal of Geophysical Research, 103, 17,279-17,292, 1998. 10.1029/97JA03329.

Baldwin, M. P., L. J. Gray, T. J. Dunkerton, K. Hamilton, P. H. Haynes, et al. The quasi-biennial oscillation. Reviews of Geophysics, 39, 179-229, 2001. 10.1029/1999RG000073.

Barrera-Escoda, A., and M. C. Llasat. Evolving flood patterns in a Mediterranean region (1301-2012) and climatic factors - the case of Catalonia. Hydrology and Earth System Sciences, 19, 465-483, 2015. 10.5194/hess-19-465-2015.

Beig, G., J. Scheer, M. G. Mlynczak, and P. Keckhut. Overview of the temperature response in the mesosphere and lower thermosphere to solar activity. Reviews of Geophysics, 46, RG3002, 2008. 10.1029/2007RG000236.

Benito, G., A. Diez-Herrero, and M. Fernandez de Villalta. Magnitude and frequency of flooding in the Tagus basin (Central Spain) over the last millennium. Climatic Change, 58, 171-192, 2003.

Berggren, A.-M., J. Beer, G. Possnert, A. Aldahan, P. Kubik, M. Christl, S. J. Johnsen, J. Abreu, and B. M. Vinther. A 600 -year annual ${ }^{10}$ Be record from the NGRIP ice core, Greenland. Geophysical Research Letters, 36, L11801, 2009. 10.1029/2009GL038004.

Birkeland, K. The Norwegian aurora Polaris expedition 1902-1903. Aschhoug, 1908.

Brasseur, G. P., and S. Solomon. Aeronomy of the Middle Atmosphere: Chemistry and Physics of the Stratosphere and Mesosphere. Springer, 2005.

Brest, C. L., W. B. Rossow, and M. D. Roiter. Update of radiance calibrations for ISCCP. Journal of Atmospheric and Oceanic Technology, 14(5), 1091-1109, 1997.

Butler, A. H., and L. M. Polvani. El Niño, La Niña, and stratospheric sudden warmings: A reevaluation in light of the observational record. Geophysical Research Letters, 38, L13807, 2011. 10.1029/2011GL048084. 
Calvo, N., M. A. Giorgetta, R. Garcia-Herrera, and E. Manzini. Correction to "Nonlinearity of the combined warm ENSO and QBO effects on the Northern Hemisphere polar vortex in MAECHAM5 simulations". Journal of Geophysical Research (Atmospheres), 114, D20117, 2009. 10.1029/2009JD013257.

Calvo, N., and D. R. Marsh. The combined effects of ENSO and the 11 year solar cycle on the Northern Hemisphere polar stratosphere. Journal of Geophysical Research (Atmospheres), 116, D23112, 2011. 10.1029/2010JD015226.

Camp, C. D., and K.-K. Tung. The Influence of the Solar Cycle and QBO on the Late-Winter Stratospheric Polar Vortex. Journal of Atmospheric Sciences, 64, 1267, 2007. 10.1175/JAS3883.1.

CCMVAL, S. SPARC Report on the Evaluation of Chemistry-Climate Models. SPARC Report No. 5, WCRP-132, WMO/TD-No. 1526. Eyring, V., Shepherd, T. G., Waugh, D. W., 2010.

Chiodo, G., D. R. Marsh, R. Garcia-Herrera, N. Calvo, and J. A. García. On the detection of the solar signal in the tropical stratosphere. Atmospheric Chemistry \& Physics, 14, 5251-5269, 2014. 10.5194/acp-14-5251-2014.

Christian, H. J., R. J. Blakeslee, D. J. Boccippio, W. L. Boeck, D. E. Buechler, et al. Global frequency and distribution of lightning as observed from space by the Optical Transient Detector. Journal of Geophysical Research (Atmospheres), 108, 4005, 2003. 10.1029/2002JD002347.

Chronis, T. G. Investigating Possible Links between Incoming Cosmic Ray Fluxes and Lightning Activity over the United States. Journal of Climate, 22, 5748, 2009. 10.1175/2009JCLI2912.1.

Clilverd, M. A., C. J. Rodger, T. Moffat-Griffin, E. Spanswick, P. Breen, F. W. Menk, R. S. Grew, K. Hayashi, and I. R. Mann. Energetic outer radiation belt electron precipitation during recurrent solar activity. Journal of Geophysical Research (Space Physics), 115, A08323, 2010. 10.1029/2009JA015204.

Crutzen, P. J., I. S. A. Isaksen, and G. C. Reid. Solar proton events - Stratospheric sources of nitric oxide. Science, 189, 457-459, 1975. 10.1126/science.189.4201.457.

Damon, P. E., and P. Laut. Pattern of strange errors plagues solar activity and terrestrial climate data. EOS, Transactions American Geophysical Union, 85(39), 370-374, 2004.

Dumbović, M., B. Vrsnak, J. Čalogović, and M. Karlica. Cosmic ray modulation by solar wind disturbances. Astronomy and Astrophysics, 531, 91, 2011.

Dunne, E., L. Lee, C. Reddington, and K. Carslaw. No statistically significant effect of a short-term decrease in the nucleation rate on atmospheric aerosols. Atmospheric Chemistry and Physics, 12(23), 11,573-11,587, 2012. 
Ermolli, I., K. Matthes, T. Dudok de Wit, N. A. Krivova, K. Tourpali, et al. Recent variability of the solar spectral irradiance and its impact on climate modelling. Atmospheric Chemistry and Physics, 13, 3945-3977, 2013. 10.5194/acp-13-39452013, 1303.5577.

Fairfield, D., and L. J. Cahill. Transition region magnetic field and polar magnetic disturbances. Journal of Geophysical research, 71, 1966.

Farrar, P. D. Are cosmic rays influencing oceanic cloud coverage-or is it only El Nino? Climatic Change, 47(1-2), 7-15, 2000.

Frame, T. H. A., and L. J. Gray. The 11-Yr Solar Cycle in ERA-40 Data: An Update to 2008. Journal of Climate, 23, 2213-2222, 2010. 10.1175/2009JCLI3150.1.

Funke, B., A. Baumgaertner, M. Calisto, T. Egorova, C. H. Jackman, et al. Composition changes after the "Halloween" solar proton event: the High Energy Particle Precipitation in the Atmosphere (HEPPA) model versus MIPAS data intercomparison study. Atmospheric Chemistry \&6 Physics, 11, 9089-9139, 2011. 10.5194/acp-11-9089-2011.

Funke, B., M. López-Puertas, G. P. Stiller, and T. Clarmann. Mesospheric and stratospheric $\mathrm{NO}_{y}$ produced by energetic particle precipitation during 20022012. Journal of Geophysical Research (Atmospheres), 119, 4429-4446, 2014. 10.1002/2013JD021404.

Gerber, E. P., A. Butler, N. Calvo, A. Charlton-Perez, M. Giorgetta, et al. Assessing and understanding the impact of stratospheric dynamics and variability on the earth system. Bulletin of the American Meteorological Society, 25, 845-859, 2012. 10.1175/BAMS-D-11-00145.1.

Gray, L. J., J. Beer, M. Geller, J. D. Haigh, M. Lockwood, et al. Solar Influences on Climate. Reviews of Geophysics, 48, RG4001, 2010. 10.1029/2009RG000282.

Gurevich, A. V., and A. N. Karashtin. Runaway Breakdown and Hydrometeors in Lightning Initiation. Physical Review Letters, 110(18), 185005, 2013. 10.1103/PhysRevLett.110.185005.

Haigh, J. D. The Sun and the Earth's Climate. Living Reviews in Solar Physics, 4, 2, 2007. 10.12942/lrsp-2007-2.

Hansen, K., K., C. Matthes, J. Petrick, and W. Wang. The influence of natural and anthropogenic factors on major stratospheric sudden warmings. Journal of Geophysical Research, 119, 8117-8136, 2014.

Harrison, R., and I. Usoskin. Solar modulation in surface atmospheric electricity. Journal of Atmospheric and Solar-Terrestrial Physics, 72, 176-182, 2010. 10.1016/j.jastp.2009.11.006. 
Harrison, R. G. The Carnegie Curve. Surveys in Geophysics, 34, 209-232, 2013. $10.1007 / \mathrm{s} 10712-012-9210-2$.

Holton, J. R. An Introduction to Dynamic Meteorology. Elsevier Academic Press, 4th edn., 2004. ISBN: 0-12-354016-X.

Holton, J. R., and H.-C. Tan. The Influence of the Equatorial Quasi-Biennial Oscillation on the Global Circulation at $50 \mathrm{mb}$. Journal of Atmospheric Sciences, 37, 2200-2208, 1980. 10.1175/1520-0469(1980)037¡2200:TIOTEQ¿2.0.CO;2.

Idso, C. D., R. M. Carter, and S. F. Singer, eds. Climate Change Reconsidered II: Physical Science. Heartland Institute, 2013.

Ineson, S., and A. A. Scaife. The role of the stratosphere in the European climate response to El Niño. Nature Geoscience, 2, 32-36, 2009. 10.1038/ngeo381.

Jackman, C. H., D. R. Marsh, F. M. Vitt, R. R. Garcia, C. E. Randall, E. L. Fleming, and S. M. Frith. Long-term middle atmospheric influence of very large solar proton events. Journal of Geophysical Research (Atmospheres), 114, D11304, 2009. 10.1029/2008JD011415.

Kirkby, J., J. Curtius, J. Almeida, E. Dunne, J. Duplissy, et al. Role of sulphuric acid, ammonia and galactic cosmic rays in atmospheric aerosol nucleation. Nature, 476(7361), 429-433, 2011.

Kodera, K., and Y. Kuroda. Dynamical response to the solar cycle. Journal of Geophysical Research (Atmospheres), 107, 4749, 2002. 10.1029/2002JD002224.

Koren, I., O. Altaratz, L. A. Remer, G. Feingold, J. V. Martins, and R. H. Heiblum. Aerosol-induced intensification of rain from the tropics to the mid-latitudes. Nature Geoscience, 5(2), 118-122, 2012.

Kristjánsson, J., J. Kristiansen, and E. Kaas. Solar activity, cosmic rays, clouds and climate-an update. Advances in space research, 34(2), 407-415, 2004.

Labitzke, K., M. Kunze, and S. Brönnimann. Sunspots, the QBO and the stratosphere in the North Polar Region - 20 years later. Meteorologische Zeitschrift, 15, 355-363, 2006. 10.1127/0941-2948/2006/0136.

Labitzke, K., and H. van Loon. Associations between the 11-Year Solar Cycle, the Quasi-Biennial Oscillation and the Atmosphere: A Summary of Recent Work. Royal Society of London Philosophical Transactions Series A, 330, 577-589, 1990. $10.1098 /$ rsta.1990.0039.

Laken, B. A., and J. Čalogović. Composite analysis with Monte Carlo methods: an example with cosmic rays and clouds. Journal of Space Weather and Space Climate, 3, A29, 2013a. 
Laken, B. A., and J. Čalogović. Does the diurnal temperature range respond to changes in the cosmic ray flux? Environmental Research Letters, 8(4), 045,018, 2013b.

Laken, B. A., E. Pallé, J. Čalogović, and E. M. Dunne. A cosmic ray-climate link and cloud observations. Journal of Space Weather and Space Climate, 2, A18, 2012 .

Laut, P. Solar activity and terrestrial climate: an analysis of some purported correlations. Journal of Atmospheric and Solar-Terrestrial Physics, 65(7), 801$812,2003$.

Lethbridge, M. D. Cosmic rays and thunderstorm frequency. Geophysical Research Letters, 8, 521, 1981. 10.1029/GL008i005p00521.

Lilensten, J., T. Dudok de Wit, P.-O. Amblard, J. Aboudarham, F. Auchère, and M. Kretzschmar. Recommendation for a set of solar EUV lines to be monitored for aeronomy applications. Annales Geophysicae, 25, 1299-1310, 2007. 10.5194/angeo-25-1299-2007.

Liu, W. The dynamic magnetospheres. IAGA Special Sopron Book Series 3, 2011.

Llasat, M.-C., M. Barriendos, A. Barrera, and T. Rigo. Floods in Catalonia (NE Spain) since the 14th century. Climatological and meteorological aspects from historical documentary sources and old instrumental records. Journal of Hydrology, 313, 32-47, 2005. 10.1016/j.jhydrol.2005.02.004.

Lockwood, M., and C. Fröhlich. Recent oppositely directed trends in solar climate forcings and the global mean surface air temperature. Proceedings of the Royal Society A: Mathematical, Physical and Engineering Science, 463(2086), 24472460, 2007.

Mann, I. R., T. P. O'Brien, and D. K. Milling. Correlations between ULF wave power, solar wind speed, and relativistic electron flux in the magnetosphere: solar cycle dependence. Journal of Atmospheric and Solar-Terrestrial Physics, 66, 187198, 2004. 10.1016/j.jastp.2003.10.002.

Markson, R. The Global Circuit Intensity: Its Measurement and Variation over the Last 50 Years. Bulletin of the American Meteorological Society, 88, 223, 2007. 10.1175/BAMS-88-2-223.

Marsh, N. D., and H. Svensmark. Low cloud properties influenced by cosmic rays. Physical Review Letters, 85(23), 5004, 2000.

Matthes, K., K. Kodera, R. R. Garcia, Y. Kuroda, D. R. Marsh, and K. Labitzke. The importance of time-varying forcing for QBO modulation of the atmospheric 11 year solar cycle signal. Journal of Geophysical Research (Atmospheres), 118, 4435-4447, 2013. 10.1002/jgrd.50424. 
Meehl, G. A., and J. M. Arblaster. A Lagged Warm Event-Like Response to Peaks in Solar Forcing in the Pacific Region. Journal of Climate, 22, 3647-3660, 2009. 10.1175/2009JCLI2619.1.

Meehl, G. A., J. M. Arblaster, K. Matthes, F. Sassi, and H. van Loon. Amplifying the Pacific Climate System Response to a Small 11-Year Solar Cycle Forcing. Science, 325, 1114-, 2009. 10.1126/science.1172872.

Moffa-Sánchez, P., A. Born, I. R. Hall, D. J. R. Thornalley, and S. Barker. Solar forcing of North Atlantic surface temperature and salinity over the past millennium. Nature Geoscience, 7, 275-278, 2014. 10.1038/ngeo2094.

Pierce, J., and P. Adams. Can cosmic rays affect cloud condensation nuclei by altering new particle formation rates? Geophysical Research Letters, 36(9), 2009.

Pinto Neto, O., I. R. C. A. Pinto, and O. Pinto. The relationship between thunderstorm and solar activity for Brazil from 1951 to 2009. Journal of Atmospheric and Solar-Terrestrial Physics, 98, 12-21, 2013. 10.1016/j.jastp.2013.03.010.

Ramanathan, V., R. Cess, E. Harrison, P. Minnis, B. Barkstrom, E. Ahmad, and D. Hartmann. Cloud-radiative forcing and climate: Results from the Earth Radiation Budget Experiment. Science, 243(4887), 57-63, 1989.

Randall, C. E., V. L. Harvey, D. E. Siskind, J. France, P. F. Bernath, C. D. Boone, and K. A. Walker. $\mathrm{NO}_{x}$ descent in the Arctic middle atmosphere in early 2009. Geophysical Research Letters, 36, L18811, 2009. 10.1029/2009GL039706.

Richter, J. H., K. Matthes, N. Calvo, and L. J. Gray. Influence of the quasibiennial oscillation and El Niño-Southern Oscillation on the frequency of sudden stratospheric warmings. Journal of Geophysical Research (Atmospheres), 116, D20111, 2011. 10.1029/2011JD015757.

Robock, A. Volcanic eruptions and climate. Reviews of Geophysics, 38, 191-219, 2000. 10.1029/1998RG000054.

Rodger, C. J., T. Raita, M. A. Clilverd, A. Seppälä, S. Dietrich, N. R. Thomson, and T. Ulich. Observations of relativistic electron precipitation from the radiation belts driven by EMIC waves. Geophysical Research Letters, 35, L16106, 2008. 10.1029/2008GL034804.

Rosenfeld, D., Y. Kaufman, and I. Koren. Switching cloud cover and dynamical regimes from open to closed Benard cells in response to the suppression of precipitation by aerosols. Atmospheric Chemistry and Physics, 6(9), 2503-2511, 2006.

Rostoker, G., S. Skone, and D. N. Baker. On the origin of relativistic electrons in the magnetosphere associated with some geomagnetic storms. Geophysical Research Letters, 25, 3701-3704, 1998. 10.1029/98GL02801. 
Rozanov, E., L. Callis, M. Schlesinger, F. Yang, N. Andronova, and V. Zubov. Atmospheric response to $\mathrm{NO}_{y}$ source due to energetic electron precipitation. Geophysical Research Letters, 32, L14811, 2005. 10.1029/2005GL023041.

Rycroft, M. J., S. Israelsson, and C. Price. The global atmospheric electric circuit, solar activity and climate change. Journal of Atmospheric and Solar-Terrestrial Physics, 62, 1563-1576, 2000. 10.1016/S1364-6826(00)00112-7.

Schlegel, K., G. Diendorfer, S. Thern, and M. Schmidt. Thunderstorms, lightning and solar activity-Middle Europe. Journal of Atmospheric and Solar-Terrestrial Physics, 63, 1705-1713, 2001. 10.1016/S1364-6826(01)00053-0.

Schumann, W. O. Über die strahlungslosen Eigenschwingungen einer leitenden Kugel die von einer Luftschicht und einer Ionosphärenhülle umgeben ist. Zeitschrift Naturforschung Teil A, 7, 149, 1952.

Seppälä, A., H. Lu, M. A. Clilverd, and C. J. Rodger. Geomagnetic activity signatures in wintertime stratosphere wind, temperature, and wave response. Journal of Geophysical Research (Atmospheres), 118, 2169-2183, 2013. 10.1002/jgrd.50236.

Siingh, D., P. R. Kumar, M. N. Kulkarni, R. P. Singh, and A. K. Singh. Lightning, convective rain and solar activity — Over the South/Southeast Asia. Atmospheric Research, 120, 99-111, 2013. 10.1016/j.atmosres.2012.07.026.

Snow-Kropla, E., J. Pierce, D. Westervelt, and W. Trivitayanurak. Cosmic rays, aerosol formation and cloud-condensation nuclei: sensitivities to model uncertainties. Atmospheric Chemistry and Physics, 11(8), 4001-4013, 2011.

Soukharev, B. E., and L. L. Hood. Solar cycle variation of stratospheric ozone: Multiple regression analysis of long-term satellite data sets and comparisons with models. Journal of Geophysical Research (Atmospheres), 111, D20314, 2006. 10.1029/2006JD007107.

Stenchikov, G., A. Robock, V. Ramaswamy, M. D. Schwarzkopf, K. Hamilton, and S. Ramachandran. Arctic Oscillation response to the 1991 Mount Pinatubo eruption: Effects of volcanic aerosols and ozone depletion. Journal of Geophysical Research (Atmospheres), 107, 4803, 2002. 10.1029/2002JD002090.

Stocker, T., and D. Qin, eds. Climate Change 2013 - The Physical Science Basis. Working Group I Contribution to the Fifth Assessment Report of the IPCC. Cambridge University Press, Cambridge, 2014.

Stubenrauch, C., W. Rossow, S. Kinne, S. Ackerman, G. Cesana, et al. Assessment of global cloud datsasets from satellites: Project and database initiated by the GEWEX Radiation Panel. Bulletin of the American Meteorological Society, 94(7), 1031-1049, 2013.

Svensmark, H. Cosmoclimatology: a new theory emerges. Astronomy \& Geophysics, 48(1), 1-18, 2007. 
Svensmark, H., and E. Friis-Christensen. Variation of cosmic ray flux and global cloud coverage - a missing link in solar-climate relationships. Journal of Atmospheric and Solar-Terrestrial Physics, 59(11), 1225-1232, 1997.

Takahashi, K. Magnetospheric ULF: Synthesis and New Directions. AGU, 2006.

Tanskanen, E. I. A comprehensive high-throughput analysis of substorms observed by IMAGE magnetometer network: Years 1993-2003 examined. Journal of Geophysical Research (Space Physics), 114, A05204, 2009. 10.1029/2008JA013682.

Tanskanen, E. I., J. A. Slavin, A. J. Tanskanen, A. Viljanen, T. I. Pulkkinen, H. E. J. Koskinen, A. Pulkkinen, and J. Eastwood. Magnetospheric substorms are strongly modulated by interplanetary high-speed streams. Geophysical Research Letters, 32, L16104, 2005. 10.1029/2005GL023318.

Tinsley, B. A. Influence of solar wind on the global electric circuit, and inferred effects on cloud microphysics, temperature, and dynamics in the troposphere. Space Science Reviews, 94(1-2), 231-258, 2000.

Toohey, M., K. Krüger, M. Bittner, C. Timmreck, and H. Schmidt. The impact of volcanic aerosol on the Northern Hemisphere stratospheric polar vortex: mechanisms and sensitivity to forcing structure. Atmospheric Chemistry \& Physics, 14, 13,063-13,079, 2014. 10.5194/acp-14-13063-2014.

van Loon, H., and K. Labitzke. The Southern Oscillation. Part V: The Anomalies in the Lower Stratosphere of the Northern Hemisphere in Winter and a Comparison with the Quasi-Biennial Oscillation. Monthly Weather Review, 115, 357, 1987. 10.1175/1520-0493(1987)115¡0357:TSOPVT¿2.0.CO;2.

van Loon, H., G. A. Meehl, and D. J. Shea. Coupled air-sea response to solar forcing in the Pacific region during northern winter. Journal of Geophysical Research (Atmospheres), 112, D02108, 2007. 10.1029/2006JD007378.

Vaquero, J. M. Solar signal in the number of floods recorded for the Tagus river basin over the last millennium. Climatic Change, 66, 23-26, 2004.

Whipple, F. J. W. On the association of the diurnal variation of electric potential gradient in fine weather with the distribution of thunderstorms over the globe. Quarterly Journal of the Royal Meteorological Society, 55, 1-18, 1929. 10.1002/qj.49705522902.

Wilson, C. T. R. Investigations on Lightning Discharges and on the Electric Field of Thunderstorms. Royal Society of London Philosophical Transactions Series A, 221, 73-115, 1921. 10.1098/rsta.1921.0003.

Yu, F., and G. Luo. Effect of solar variations on particle formation and cloud condensation nuclei. Environmental Research Letters, 9(4), 045,004, 2014.

$\mathrm{Yu}, \mathrm{F}$., and R. P. Turco. Ultrafine aerosol formation via ion-mediated nucleation. Geophysical Research Letters, 27(6), 883-886, 2000. 